\title{
Past daily light cycle recorded in the strontium/ calcium ratios of giant clam shells
}

Yuji Sano ${ }^{1}$, Sayumi Kobayashi ${ }^{1} \uparrow$, , Kotaro Shirai ${ }^{1}$, Naoto Takahata ${ }^{1}$, Katsumi Matsumoto ${ }^{2}$, Tsuyoshi Watanabe ${ }^{3}$, Kohki Sowa ${ }^{3} \&$ Kenji Iwai ${ }^{4}$

The historical record of daily light cycle in tropical and subtropical regions is short. Moreover, it remains difficult to extract this cycle in the past from natural archives such as biogenic marine carbonates. Here we describe the precise analysis of $\mathrm{Sr} / \mathrm{Ca}, \mathrm{Mg} / \mathrm{Ca}$, and $\mathrm{Ba} / \mathrm{Ca}$ ratios in a cultivated giant clam shell, using a laterally high-resolution secondary ion mass spectrometer with $2 \mu \mathrm{m}$ resolution. The $\mathrm{Sr} / \mathrm{C}$ a ratio exhibits striking diurnal variations, reflecting the daily light cycle. A clear seasonal variation in $\mathrm{Sr} / \mathrm{C}$ a is also observed in another longer set of measurements with $50 \mu \mathrm{m}$ resolution. Light-enhanced calcification and elemental transportation processes, in giant clam and symbiotic algae, may explain these diurnal and annual variations. This opens the possibility to develop the Sr/Ca ratio from a giant clam shell as an effective proxy for parameters of the daily light cycle.

\footnotetext{
${ }^{1}$ Atmosphere and Ocean Research Institute, University of Tokyo, Kashiwa, Chiba 277-8564, Japan. ${ }^{2}$ Department of Earth Sciences, University of Minnesota, Minneapolis, Minnesota 55455, USA. ${ }^{3}$ Department of Earth and Planetary Sciences, Hokkaido University, Kitaku, Sapporo 060-0810, Japan.

${ }^{4}$ Ishigaki Branch, Research Center of Fishery and Oceanography at Okinawa Prefecture, Ishigaki, Okinawa 907-0453, Japan. 'Present address: Toshiba Electronic Company. Correspondence and requests for materials should be addressed to Y.S. (email: ysano@aori.u-tokyo.ac.jp).
} 
$\mathrm{n}$ tropical and subtropical regions, instrumental records as well as historical documents are relatively short compared with those in the temperate zones. Also, dendroclimatology is difficult to apply in low latitudes. Thus, biogenic marine carbonates are important tools for reconstruction of the past climate system. Proxies reflecting past seawater temperature ${ }^{1-3}$, salinity ${ }^{4,5}, \mathrm{pH}^{6,7}$, and nutrients ${ }^{8,9}$ has been derived from stable isotopes and trace elements in coral skeletons, foraminifera tests, and mollusk shells. Insolation is an important component of meteorological data, as solar energy is the primal and direct driver of weather and climate. Proxy development for reconstruction of light cycle can open new opportunities on past climate study; in that, the insolation is a 'driving force' whereas conventional proxies reconstruct the consequential 'environment'. Few attempts have been made to estimate the past light cycle with hourly insolation, using environmental proxies such as carbonate chemistry and isotopes ${ }^{10,11}$, but none has succeeded. Several recent microanalytical studies have extracted valuable knowledge related to palaeoclimate data ${ }^{12,13}$, but not the daily light cycle.

In this study, we analysed strontium/calcium of giant clam shells with a $2-\mu \mathrm{m}$ resolution using laterally high-resolution secondary ion mass spectrometry. We observe synchronous, daily variations in $\mathrm{Sr} / \mathrm{Ca}$ and growth-banding pattern, pointing to the possibility of reconstructing daily light cycle at a few hour timescale. This is the finest spatial resolution in the literature of carbonate geochemistry.

\section{Results}

Sample description and Sr/Ca imaging. Live giant clams (Tridacna derasa) were collected from Kabira coral reef at Ishigaki Island $\left(124^{\circ} 09^{\prime} \mathrm{E}, 24^{\circ} 20^{\prime} \mathrm{N}\right)$ in the southwestern part of the Ryukyu Archipelago, southern Japan, on October 14, 2005. Kabira is a welldeveloped fringing coral reef with a typical zonation from land to ocean including a moat, inner reef flat, reef crest, outer reef flat, and reef slope. The sampled $T$. derasa had been cultivated in the reef since 27 March 2002, and environmental data such as precipitation, temperature, insolation, sea level, and seawater temperature were measured automatically in the reef and documented until the collection date. After removing the soft tissue, the centre of one side of the shell was cut from its umbo to the ventral margin along the maximum growth axis (Fig. 1a). Then a radial section was prepared using a dental cutting machine (Fig. 1b). An inner layer part was mounted in epoxy resin disk together with a carbonate standard (Fig. 1c). This species is known to form a growth line each day ${ }^{14-16}$, and to facilate age-model determination by counting growth lines, $\mathrm{Sr}$ enrichment band was measured using an electron probe microanalyzer (EPMA; Fig. 1d,e). On cloudy or rainy days, there were probably irregular Sr bands for the day, which can be corrected to assign calendar date (Methods).

High-resolution profiles. Four sets of trace element profiles for $\mathrm{Sr} / \mathrm{Ca}, \mathrm{Mg} / \mathrm{Ca}$, and $\mathrm{Ba} / \mathrm{Ca}$ ratios from two individual $\mathrm{T}$. derasa were obtained using a laterally high-resolution secondary ion mass spectrometer ${ }^{17}$, (NanoSIMS) along the growth axis of the juvenile clam shell. In the first, 'high'-resolution set measurements were made along the growth axis with a $2-\mu \mathrm{m}$ spot at $2 \mu \mathrm{m}$ interval from the inner edge (Fig. 1c). The edge was last calcified and is thus expected to correspond to the sample collection date. The error in the Sr/Ca measurement is about $2 \%(1 \sigma)$ as estimated by repeated measurements of a standard calcite. Because the collection time is known, it is possible to determine the calendar dates for this record by counting growth layers from the inner edge. The $\mathrm{Sr} / \mathrm{Ca}$ ratio varies regularly and indicates a clear diurnal signal (Fig. 2a), suggesting that environmental parameters such as solar radiation and/or temperature drive the giant clam shell $\mathrm{Sr} / \mathrm{Ca}$ geochemistry. The conclusion that the $\mathrm{Sr} / \mathrm{Ca}$ ratio reflects the diurnal signal is robust and significant, because the $\mathrm{Sr} / \mathrm{Ca}$ variability shown in Fig. 2a is reproduced in the second set of high-resolution measurements obtained from


Figure 1 | Photograph of cutting section and strontium imaging of giant clam shell. (a) Photograph of T. derara cultivated at Ishigaki Island in the southwestern part of Ryukyu Archipelago, southern Japan. A dotted arrow indicates the vertical cutting section of the half-valve. (b) Section of the half-valve. The black bar shown at the bottom denotes a 2-cm scale bar. (c) Photograph of the cutting section obtained using a commercial photo scanner anlaysed in this work together with small figures obtained using an EPMA. The trajectory of the figures coincides with that of SIMS analysis (d) Composite image ( $\mathrm{Cp}$ ) and Sr concentration map ( $\mathrm{Sr}$ ) of the sample enlarged from a red square marked in (c). Dates were counted using the daily growth lines with Sr enrichment bands. (e) Enlarged image of Sr concentration map of another region measured using an EPMA. The high and low Sr contents show thin and thick bands.

a different $T$. derasa individual living at the same location during the same time period (Supplementary Fig. S1). Interestingly, the number of data representing a single day is approximately twice in the first record shown in Fig. 2 than in the second record. As both data sets had the same $2-\mu \mathrm{m}$ sampling resolution, the daily bandwidth is different by a factor of two, indicating that the growth rate can be quite variable among the individuals living under presumably the same environmental conditions.

Low-resolution profiles. The third and longest set of new Sr/Ca data, which is referred to here as the 'low'-resolution record, spans 2 years of growth (Fig. 3). Measurements were made with $10-\mu \mathrm{m}$ diameter spots at $50 \mu \mathrm{m}$ interval along the same growth line in the same bivalve sample, from which the high-resolution data were obtained. The annual variation of $\mathrm{Sr} / \mathrm{Ca}$ ratios, low in summer and high in winter, is clearly visible. This general trend is observable and confirmed by ICP-MS measurements (Supplementary Fig. S2). The analytical error of the $\mathrm{Sr} / \mathrm{Ca}$ ratio in this long record is again $~ 2 \%$ $(1 \sigma)$. The age model for this record was guided by our preliminary conclusion that calcification rate is faster, and growth band is wider during the day than night (see Discussion and Methods for more details of the age model and the fourth data set, which presents four short segments of the long record at select intervals at high resolution).

As a result of how the age model was constructed and because insolation variation leads water temperature variation, the lowresolution $\mathrm{Sr} / \mathrm{Ca}$ record also has a negative correlation with monthly mean insolation, but not with monthly mean water temperature 

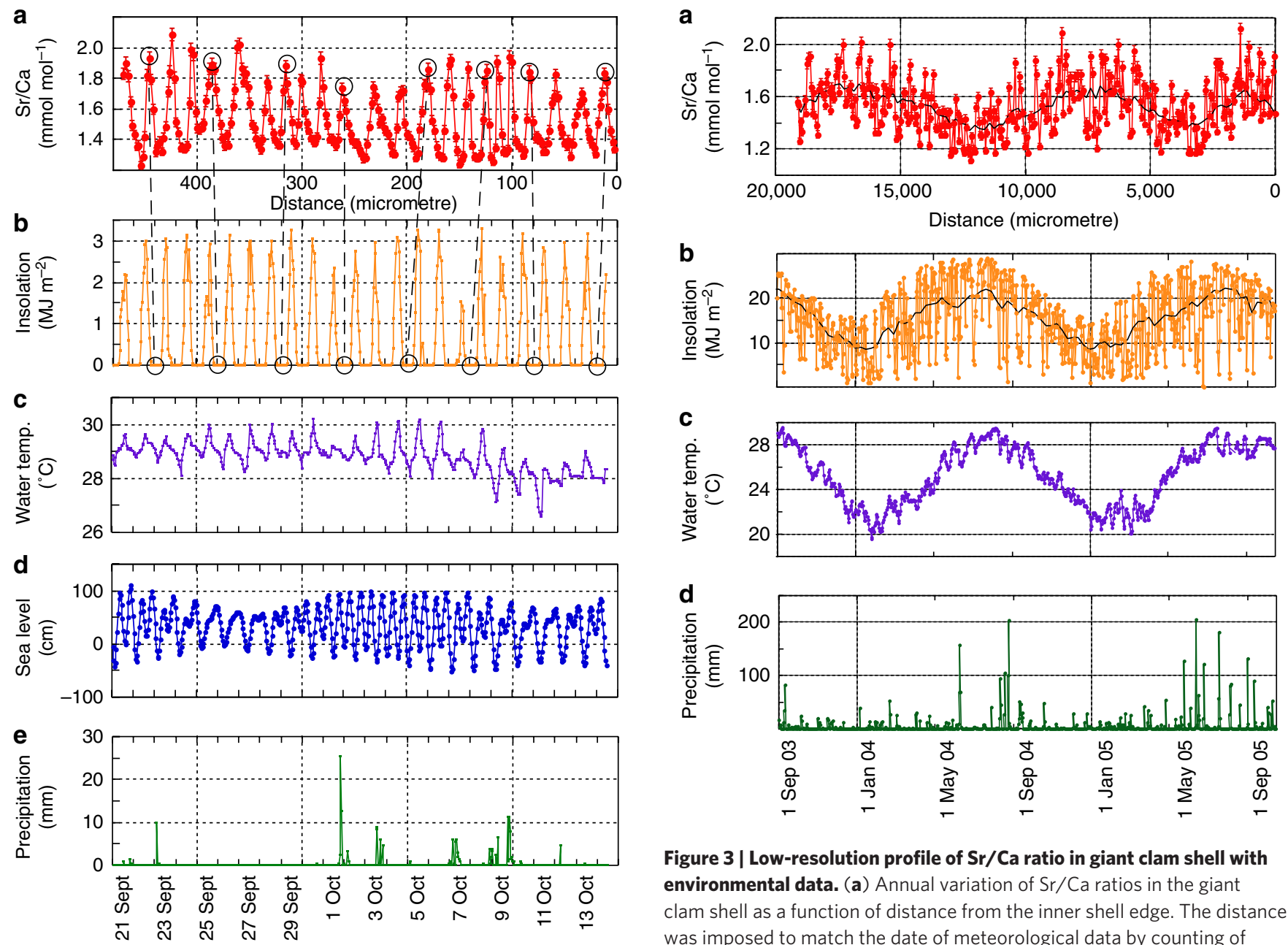

Figure 2 | High-resolution profile of $\mathrm{Sr} / \mathrm{Ca}$ ratio in giant clam shell with environmental data. (a) Diurnal variation of $\mathrm{Sr} / \mathrm{Ca}$ in the giant clam shell as a function of distance from the inner shell edge. The distance was imposed to match the date of meteorological data by a counting of daily growth lines. Error assigned to the symbol is $1 \sigma$. (b) Record of insolation during the time interval of $\mathrm{Sr} / \mathrm{Ca}$ observation at Ishigaki Island. (c) Surface seawater temperatures at Shiraho coral reef, close to Kabira, at the island where the giant clam was cultivated. (d) Record of sea level at Shraho coral reef. (e) Precipitation record at Ishigaki Island.

(Fig. 3; Supplementary Fig. S3). We note that a previous study, which measured $\mathrm{Sr} / \mathrm{Ca}$ in a different bivalve species Tridacna gigas, showed no clearly reproducible seasonal trend ${ }^{18}$. The discrepancy with this work may be attributable to the coarser analytical spatial resolution $(70-\mu \mathrm{m}$ spot diameter by laser ablation ICP-MS), or to the particular age of the clam individual used in the previous study.

The associated low-resolution $\mathrm{Mg} / \mathrm{Ca}$ and $\mathrm{Ba} / \mathrm{Ca}$ measurements (Supplementary Fig. S4) show features similar to the same measurements made in the high-resolution record (Fig. 4). Namely, both $\mathrm{Mg} / \mathrm{Ca}$ and $\mathrm{Ba} / \mathrm{Ca}$ records are spiker than $\mathrm{Sr} / \mathrm{Ca}$, and $\mathrm{Ba} / \mathrm{Ca}$ show no obvious correlation to $\mathrm{Sr} / \mathrm{Ca}$.

\section{Discussion}

In this study, layer counting does not allow definitive determination of how $\mathrm{Sr} / \mathrm{Ca}$ varies with time, as the growth rate is not known and probably varies with time. Specifically, it is unclear a priori which parts of the diurnal $\mathrm{Sr} / \mathrm{Ca}$ variation correspond to day and night. In Fig. 2a, Sr/Ca peaks generally consist of few data points, whereas the

Figure 3 | Low-resolution profile of $\mathrm{Sr} / \mathrm{Ca}$ ratio in giant clam shell with environmental data. (a) Annual variation of $\mathrm{Sr} / \mathrm{Ca}$ ratios in the giant clam shell as a function of distance from the inner shell edge. The distance was imposed to match the date of meteorological data by counting of daily growth lines. Error assigned to the symbol is $1 \sigma$. (b) Record of insolation during the possible time interval of $\mathrm{Sr} / \mathrm{Ca}$ observation at Ishigaki Island. (c) Surface seawater temperature in the Kabira coral reef at the island where the giant clam was cultivated. (d) Precipitation record at Ishigaki Island.

troughs consist of a larger number of data. The peaks are thus narrower than the troughs, and this is consistent with the alternating bandwidths of the Sr concentration map (Fig. 1e). Because photosynthetic activity of symbiotic dinoflagellates, and, hence, the clam shell calcification rate are expected to be enhanced by insolation ${ }^{15,19}$, the wider troughs of the $\mathrm{Sr} / \mathrm{Ca}$ variability likely represent, and thus are assigned, to daytime calcification. The narrower peaks are assigned to night time. This assignment effectively aligns $\mathrm{Sr} / \mathrm{Ca}$ variability with insolation variability, which drives water-temperature variability. However, because the heat capacity of water is high, water temperature is not able to respond immediately to insolation changes. Therefore, insolation variability leads temperature variability (Fig. 2b,c). Consequently, $\mathrm{Sr} / \mathrm{Ca}$ has a negative correlation with insolation but no correlation with temperature (Supplementary Fig. S5a,b).

The lack of a relationship with temperature is a direct consequence of the age model adopted in this work, and it is quite possible that temperature has significant impact on $\mathrm{Sr} / \mathrm{Ca}$, especially given that temperature is the major determinant in oxygen isotopic ratios of a giant clam ${ }^{15}$. However, available reports of Sr/Ca measurements on bivalve shells suggest no temperature control ${ }^{20,21}$. Also, a decreasing trend of water temperature observed from 1-13 October (Fig. 2c) has no corresponding trend in the $\mathrm{Sr} / \mathrm{Ca}$ data 
(Fig. 2a), suggesting that temperature may not be the principal driver of $\mathrm{Sr} / \mathrm{Ca}$.

Because of the ambiguity in the $\mathrm{Sr} / \mathrm{Ca}$ age model and the fact that insolation does not produce a smooth sinusoidal curve, it is not fruitful to carry out phase analysis to determine precise lead/lag relationships between $\mathrm{Sr} / \mathrm{Ca}$ and environmental variables shown in Fig. 2, which includes insolation, temperature, sea level, and precipitation. Instead, a simple autocorrelation analysis of these variables, except for precipitation that is episodic, is presented (Supplementary Fig. S6). It shows a periodic variation in the $\mathrm{Sr} / \mathrm{Ca}$ ratio over a $20-\mu \mathrm{m}$ shell distance, which likely represents mean daily growth bandwidth and a single day. Insolation and water temperature have an obvious $24 \mathrm{~h}$ cycle, whereas tidally driven semidiurnal sea level change has an $\sim 12 \mathrm{~h}$ cycle. Tidal forcing is therefore not likely the principal controller of $\mathrm{Sr} / \mathrm{Ca}$ variation in this work, even though there appear to be tidal modulations of $\mathrm{Sr} / \mathrm{Ca}$ in a Pacific reef coral $^{22}$.

The way by which the daily light cycle was assigned to $\mathrm{Sr} / \mathrm{Ca}$ variability in this study has implications on consideration of the geochemical driving mechanism of the Sr/Ca variability. The incorporation of $\mathrm{Ca}$ and $\mathrm{Sr}$ into the calcite skeleton from ambient sea water occurs in two steps: first, ionic transport from ambient sea water to extrapallial fluid (EPF); and second, precipitation from EPF to shell skeleton. Elemental fractionation that acts on these steps can cause variability in $\mathrm{Sr} / \mathrm{Ca}$ ratio in aragonite skeleton. In the first step, two mechanisms have been hypothesized to cause $\mathrm{Sr} / \mathrm{Ca}$ fractionation in bivalve shells ${ }^{20,21}$. They are the Ca-ATPase hypothesis and the Ca-channel hypothesis. According to the Ca-ATPase hypothesis, selective incorporation of $\mathrm{Ca}$ is expected at high-calcification rates, induced by enzymes activated by solar energy. This would reduce the $\mathrm{Sr} / \mathrm{Ca}$ ratio in EPF and widen the growth band during daytime. These predictions are consistent with the observations (Fig. 1e). In the Ca-channel hypothesis, however, a reduction of Ca selectivity is expected to occur at high calcification rates, thus leading opposite predictions inconsistent with observations. One other process in the second step, inorganic precipitation of aragonite, can cause kinetic fractionation without changing EPF compositions. It is expected to cause positive correlation between $\mathrm{Sr} / \mathrm{Ca}$ and precipitation $\mathrm{rate}^{23}$, so that the shell $\mathrm{Sr} / \mathrm{Ca}$ is predicted to increase as aragonite is preferentially precipitated from EPF during daytime. This is not supported by observations. The dominant mechanism that causes $\mathrm{Sr} / \mathrm{Ca}$ variability in bivalves in this study thus appears to be the Ca-ATPase process.

The high-resolution $\mathrm{Mg} / \mathrm{Ca}$ and $\mathrm{Ba} / \mathrm{Ca}$ data accompanying the $\mathrm{Sr} / \mathrm{Ca}$ data are presented in Fig. 4. The $\mathrm{Mg} / \mathrm{Ca}$ data also appear to show a diurnal cycle, but the amplitude is rather large and highly irregular. A few reports have described a positive correlation between the $\mathrm{Mg} / \mathrm{Ca}$ ratio and temperature for Mytilus trossulus ${ }^{24}$ and Crassostrea virginica ${ }^{25}$, although these earlier data were obtained using a conventional analytical method. There is a slight positive correlation between the $\mathrm{Mg} / \mathrm{Ca}$ ratio and seawater temperature (Supplementary Fig. S5d). Spike-type enrichment of $\mathrm{Mg}$ observed previously in coral skeletons ${ }^{26,27}$ resembles the observations described in this work. The irregular spikes possibly indicate the importance of other as-yet-unidentified controls, including biological controls, on $\mathrm{Mg} / \mathrm{Ca}$. As with $\mathrm{Sr} / \mathrm{Ca}$ data, $\mathrm{Mg} / \mathrm{Ca}$ has no obvious correlation with precipitation or sea level (compare Figs $2 \mathrm{~d}$,e and $4 \mathrm{a}$ ). This is supported by the autocorrelation analysis of these data. There is a periodic component in $\mathrm{Mg} / \mathrm{Ca}$ data (Supplementary Fig. S6a), whereas the precipitation is episodic. The $\mathrm{Ba} / \mathrm{Ca}$ data show large amplitude variability but no obvious diurnal cycle. Ba/Ca variation may be attributable to changes in precipitation, because $\mathrm{Ba} / \mathrm{Ca}$ is apparently affected by reef nutrient contents ${ }^{28,29}$, which are occasionally influenced by river water.

Among these high-resolution record of $\mathrm{Ba} / \mathrm{Ca}, \mathrm{Sr} / \mathrm{Ca}$ and $\mathrm{Mg} / \mathrm{Ca}$ ratios, there is no obvious correlation except for $\mathrm{Sr} / \mathrm{Ca}$ and $\mathrm{Mg} / \mathrm{Ca}$ ratios (both have a periodic component). This is in contrast to
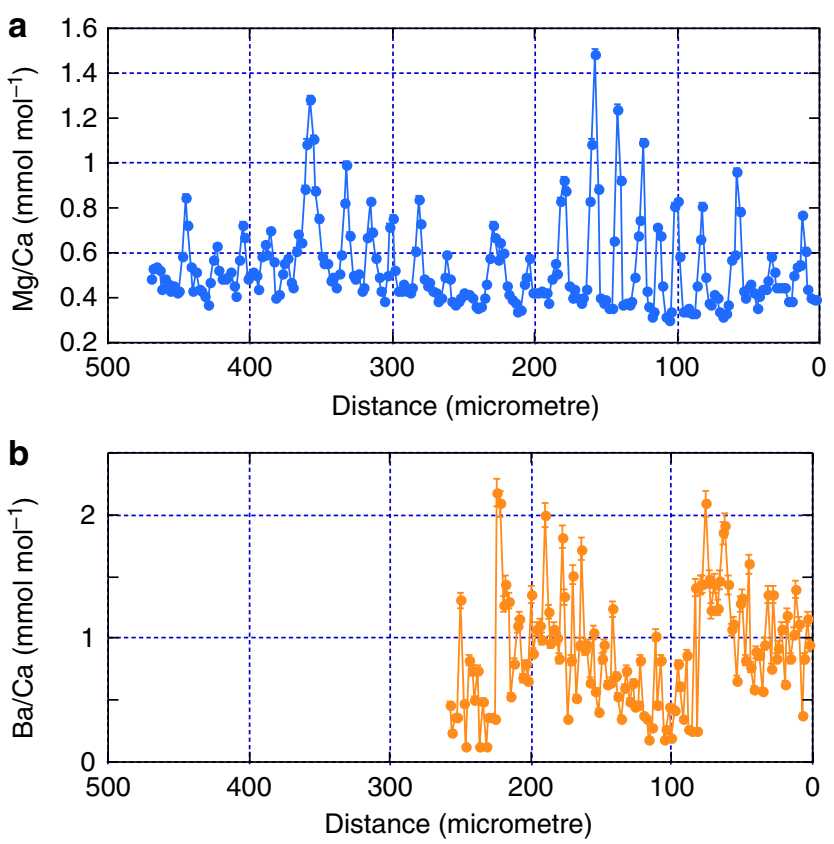

Figure 4 | High-resolution profiles of $\mathrm{Mg} / \mathrm{Ca}$ and $\mathrm{Ba} / \mathrm{Ca}$ ratios in giant clam shell. (a) $\mathrm{Mg} / \mathrm{Ca}$ ratios and (b) $\mathrm{Ba} / \mathrm{Ca}$ ratios, as a function of distance from the inner shell edge. These data correspond to the $\mathrm{Sr} / \mathrm{Ca}$ data in Fig. $2 \mathrm{a}$. Ba/Ca data between 250 and $470 \mu \mathrm{m}$ are lacking because of unexpected instability of the deflector plate located just before the ion-counting detector for ${ }^{138} \mathrm{Ba}$ ions.

observed, synchronous variations in these ratios in corals that have been attributed to changes in ambient water temperature ${ }^{30}$. This may be partly due to the stronger biological control in a giant clam than in corals.

This work presented new measurements of $\mathrm{Sr} / \mathrm{Ca}, \mathrm{Mg} / \mathrm{Ca}$ and $\mathrm{Ba} / \mathrm{Ca}$ in the finest temporal resolution to date in the carbonate geochemistry literature ${ }^{1-9}$. Although there is some ambiguity in the age model, the giant clam $\mathrm{Sr} / \mathrm{Ca}$ data clearly demonstrated the daily light cycle, which we attributed to insolation-driven, differential rates of growth and calcification. This attribution is preliminary at this time, as it is not possible to quantify other possible controls. This includes enhanced growth rates due to increased availability of nutrients or higher temperatures. Because of the regular diurnal cycle, the temperature effect in particular is a real possibility, especially as its effect on the oxygen isotope composition of carbonate shells is well documented ${ }^{15}$. To realize the possibility of developing the giant clam $\mathrm{Sr} / \mathrm{Ca}$ as a useful proxy of insolation or some other aspect of the daily light cycle, it will be necessary to establish the age model with more confidence and isolate the effects of temperate and insolation. Analysis of $\delta^{18} \mathrm{O}$ at the same $2 \mu \mathrm{m}$ resolution with a $0.1 \%$ error as the $\mathrm{Sr} / \mathrm{Ca}$ data in this work would make a significant contribution to this effort, but such analysis would be difficult given present experimental techniques. Instead, cultivation of the giant clam under different, controlled environmental settings may be more feasible. For example, cultivation at a constant temperature with ambient light can isolate the temperature control on the Sr/Ca ratio. Still easier may be controlling for light with a simple cover to shield light reaching the giant clam. Another method may be to expose the giant clam to a dye, possibly a $\mathrm{Sr}$ isotope spike (enriched ${ }^{87} \mathrm{Sr}$ ), at particular times of the day to make the times, so that the peaks and troughs of the $\mathrm{Sr} / \mathrm{Ca}$ variation can be definitively assigned to night and day. These are imminently feasible and point the way forward in realizing the exciting possibility of developing a high-resolution daily light cycle proxy. 


\section{Methods}

NanoSIMS analyses. Mounted samples were polished with a polishing sheet with fine alumina grains embedded on the surface. Final polishing was done with a $1-\mu \mathrm{m}$ alumina suspension. The polished surface was coated with Pt-Pd to avoid charging during the analysis. Measurement of major and trace elements was performed by a NanoSIMS installed at the Atmosphere and Ocean Research Institute, the University of Tokyo. There are two types of measurements; high- and lowresolution analysis. For the high resolution, a $\sim 100$-pA primary beam of ${ }^{16} \mathrm{O}^{-}$was focused, $\sim 2 \mu \mathrm{m}$ spot in diameter. For the low resolution, an $\sim 10$-nA primary beam with $10 \mu \mathrm{m}$ spot was used. Secondary ions were extracted by an accelerating voltage of $8 \mathrm{kV}$, introduced into a Mattauch-Herzog geometry, and ${ }^{24} \mathrm{Mg},{ }^{44} \mathrm{Ca},{ }^{88} \mathrm{Sr}$ and ${ }^{138} \mathrm{Ba}$ ion were measured simultaneously by multi-collector system. Molecular interference was not observed except for ${ }^{40} \mathrm{Ca}_{2}{ }^{26} \mathrm{Mg}^{16} \mathrm{O}_{2}$ on ${ }^{138} \mathrm{Ba}$ peak. The ${ }^{138} \mathrm{Ba} /$ ${ }^{44} \mathrm{Ca}$ ratio was corrected based on the observed ${ }^{24} \mathrm{Mg} /{ }^{44} \mathrm{Ca}$ ratio and the estimated ${ }^{40} \mathrm{Ca}_{2}{ }^{26} \mathrm{Mg}^{16} \mathrm{O}_{2} /{ }^{24} \mathrm{Mg}$ ratio ${ }^{17}$. All data were calibrated against a natural calcite rock from Mexico, which is homogeneous for the $\mathrm{Mg} / \mathrm{Ca}$ and $\mathrm{Sr} / \mathrm{Ca}$ ratios $^{31,32}$.

ICP-MS analyses. To check the validity of low-resolution data, the $\mathrm{Sr} / \mathrm{Ca}$ and $\mathrm{Mg} / \mathrm{Ca}$ ratios of the sample with a similar trajectory (see C-D in Supplementary Fig. S2a) parallel to the NanoSIMS analysis (A-B) were measured by ICP-MS. The clam shell was sampled by a micro-drilling machine, making a spot of about $1 \mathrm{~mm}$ diameter and $1 \mathrm{~mm}$ deep with $1.5 \mathrm{~mm}$ interval. Scraped powder was dissolved by $\mathrm{HNO}_{3}$ and prepared for the analysis. Intensities of ${ }^{9} \mathrm{Be},{ }^{24} \mathrm{Mg},{ }^{43} \mathrm{Ca},{ }^{45} \mathrm{Sc},{ }^{48} \mathrm{Ca}$, ${ }^{88} \mathrm{Sr}$, ${ }^{137} \mathrm{Ba}$ and ${ }^{209} \mathrm{Bi}$ were measured by ICP-MS where ${ }^{9} \mathrm{Be},{ }^{45} \mathrm{Sc}$ and ${ }^{209} \mathrm{Bi}$ were the internal standard elements added into the sample solution. Observed ${ }^{24} \mathrm{Mg} /{ }^{43} \mathrm{Ca}$, ${ }^{88} \mathrm{Sr} /{ }^{43} \mathrm{Ca}$ and ${ }^{137} \mathrm{Ba} /{ }^{43} \mathrm{Ca}$ ratios were calibrated against those of a standard sample (JCt-1) prepared and distributed by National Institute of Advanced Industrial Science and Technology, AIST in Japan. Both $\mathrm{Mg} / \mathrm{Ca}$ and $\mathrm{Sr} / \mathrm{Ca}$ ratios are shown in Supplementary Fig. S2b and S2c, respectively, where the NanoSIMS data are given by count ratios. There is an overall agreement, suggesting that the low-resolution data of the NanoSIMS are reliable and assured by the ICP-MS data.

Duplicate and high-resolution data. To assess the fidelity of the diurnal variation of Sr/Ca presented in Fig. 2, we have duplicated the experiment using another giant clam shell cultivated at the same location (Kabira coral reef) and time (from 27 March 2002 to 14 October 2005). Analytical conditions are the same as the first high-resolution data set using a $2-\mu \mathrm{m}$ spot with a $2-\mu \mathrm{m}$ interval at the inner edge. Variations of $\mathrm{Sr} / \mathrm{Ca}, \mathrm{Mg} / \mathrm{Ca}$ and $\mathrm{Ba} / \mathrm{Ca}$ ratios are shown in Supplementary Fig. S1. There is significant diurnal variation of $\mathrm{Sr} / \mathrm{Ca}$, which is clearly responding to the daily light cycle. It is possible to layer-count the dates, even though the morning data of the collection data are missing. The number of data in a single day is $5-7$, smaller than that of the first data set, which had about 11 data. As the experiment was precisely conducted with a $2-\mu \mathrm{m}$ interval, the daily bandwidth of this sample is smaller than that of Fig. 2 . This suggests that the growth rate is variable among the individuals, even under the same environmental conditions. The $\mathrm{Sr} / \mathrm{Ca}$ ratios of 7 October are apparently irregular, consistent with the lowest insolation during the day (Fig. 2b). On the basis of the age model of the new data in Fig. 2, there is a slight positive correlation between the $\mathrm{Sr} / \mathrm{Ca}$ and $\mathrm{Mg} / \mathrm{Ca}$ ratios. No diurnal cycle is observed in the $\mathrm{Ba} / \mathrm{Ca}$ ratio.

\section{Autocorrelation of high-resolution record and environmental conditions.} Supplementary Fig. S6 shows the autocorrelation analysis of $\mathrm{Mg} / \mathrm{Ca}$ ratio, $\mathrm{Sr} / \mathrm{Ca}$ ratio, insolation, water temperature and sea level derived from the high-resolution data presented in Fig. 2. Precipitation is not considered, because there is no periodic component to it. The horizontal axis of the $\mathrm{Mg} / \mathrm{Ca}$ and $\mathrm{Sr} / \mathrm{Ca}$ ratios is based on shell distance from the inner edge in micrometre, whereas the unit of meteorological parameters is in hour. There are apparent periodic variations of $\mathrm{Mg} / \mathrm{Ca}$ and $\mathrm{Sr} / \mathrm{Ca}$ ratios with a $20-\mu \mathrm{m}$ interval. On the other hand, the cycle is $24 \mathrm{~h}$ for the insolation and water temperature, whereas it is $12 \mathrm{~h}$ for the sea level. There are two peaks per day in sea level variation between September 30 and October 8, while only one broad peak is seen between 25 and 28 September (Fig. 2d). These temporal variations are significantly different from those of $\mathrm{Ma} / \mathrm{Ca}$ and $\mathrm{Sr} / \mathrm{Ca}$, which has generally one peak per day (Fig. 4a), suggesting that tidal forcing is not the principal control in this work, even though there are tidal modulations of $\mathrm{Sr} / \mathrm{Ca}$ ratios in a Pacific reef coral.

Relation of $\mathrm{Sr} / \mathrm{Ca}$ and $\mathrm{Mg} / \mathrm{Ca}$ to insolation and temperature. On the basis of the assigned timing of the long, low-resolution $\mathrm{Sr} / \mathrm{Ca}$ ratio data relative to meteorological data shown in Fig. 3, there is a slight negative correlation between monthly mean daily insolation and the corresponding monthly mean $\mathrm{Sr} / \mathrm{Ca}$ ratio (Supplementary Fig. S3a) but no relation between seawater temperature and the $\mathrm{Sr} / \mathrm{Ca}$ ratio (Supplementary Fig. S3b). The relationship between insolation and $\mathrm{Sr} / \mathrm{Ca}$ ratio is approximated by a method for linear curve fitting with both variables in error (York method) as

$$
\mathrm{Sr} / \mathrm{Ca}(\mathrm{mmol} / \mathrm{mol})=(1.88 \pm 0.16)-(0.023 \pm 0.009) \times \mathrm{P} 1
$$

where $\mathrm{P} 1$ denotes the daily insolation with the unit of $\mathrm{MJ} \mathrm{m}^{-2}$. Errors assigned to the slope and intercept are $1 \sigma$. The relationship may imply that the insolation control on the $\mathrm{Sr} / \mathrm{Ca}$ ratio is negative.
If the same quantitative relation is sought for the high-resolution record shown in Fig. 2, the equations would be:

$$
\mathrm{Sr} / \mathrm{Ca}(\mathrm{mmol} / \mathrm{mol})=(2.09 \pm 0.49)-(0.262 \pm 0.085) \times \mathrm{P} 2
$$

where $\mathrm{P} 2$ denotes the hourly insolation with the unit of $\mathrm{MJ} \mathrm{m}^{-2}$ and the fitting was made based on the both variable in error and the correlation coefficient is 0.230 . This relation was derived with 3-point averaged, daily peak values for $\mathrm{Sr} / \mathrm{Ca}$ and insolation. It ignored the apparent outlier of the October 7 value (Supplementary Fig. S5a). There is no apparent relationship between the $\mathrm{Sr} / \mathrm{Ca}$ and temperature with the correlation coefficient of 0.004 (Supplementary Fig. S5b).

Similar average of daily peak values for $\mathrm{Mg} / \mathrm{Ca}$ was calculated and plotted against the insolation (Supplementary Fig. S5c) and temperature (Supplementary Fig. S5d). There is a positive correlation between the $\mathrm{Mg} / \mathrm{Ca}$ and temperature with the correlation coefficient of 0.465 .

Low resolution $\mathrm{Mg} / \mathrm{Ca}$ and $\mathrm{Ba} / \mathrm{Ca}$ data. The NanoSIMS low resolution $\mathrm{Sr} / \mathrm{Ca}$ data are confirmed by ICP-MS (Supplementary Fig. S2). The NanoSIMS Mg/Ca and $\mathrm{Ba} / \mathrm{Ca}$ ratios of low-resolution data are shown in Supplementary Fig. S4. Experimental errors are $1.5 \%(1 \sigma)$ for $\mathrm{Mg} / \mathrm{Ca}$ ratios and $5 \%(1 \sigma)$ for $\mathrm{Ba} / \mathrm{Ca}$ ratios, estimated by repeated measurements of the standard calcite. In contrast to the $\mathrm{Sr} / \mathrm{Ca}$ ratio, the $\mathrm{Mg} / \mathrm{Ca}$ ratio has weak negative correlations with both the monthly mean surface seawater temperature and insolation. On the other hand, the $\mathrm{Ba} / \mathrm{Ca}$ ratio has no relation with temperature but a positive correlation to insolation.

Select intervals and uncertainty in age model in high-resolution data. The long, low-resolution $\mathrm{Sr} / \mathrm{Ca}$ data presented in Fig. 3 is examined in greater detail in four short segments at select intervals (Supplementary Fig. S7). The intervals are at distances of $1,000-1,050,2,000-2,050,3,000-3,050$, and 4,000-4,050 $\mu \mathrm{m}$ from the inner edge. Shown are $\mathrm{Sr} / \mathrm{Ca}$ and insolation, water temperature, and precipitation at estimated dates. There are two problematic aspects to the estimated dates or the age model of this long record. First, a 10\% reduction in the length of the calendar year, as determined by layer counting the Sr map bands (Fig. 1e), was necessary to bring about an overall match in the seasonal variations in $\mathrm{Sr} / \mathrm{Ca}$ and insolation. As a result, there are four Sr/Ca peaks during two very cloudy $\left(<0.5 \mathrm{MJ} \mathrm{m}^{-2}\right)$ and rainy days during 22-24 March period (Supplementary Fig. S7a.) For unexplained reasons, it seems $\mathrm{Sr} / \mathrm{Ca}$ variations do not faithfully reflect the daily light cycle on cloudy days. Without assigning double enrichment bands per day on cloudy days, the year 2004, for example, with 38 cloudy days $\left(<5 \mathrm{MJ} \mathrm{m}^{-2}\right.$ at Ishigaki Island) would have been overestimated by $10 \%$. The $\mathrm{Sr} / \mathrm{Ca}$ data presented in Fig. 3 include this $10 \%$ adjustment in lining it against meteorological data. Anyway there is a relationship between the amplitude of $\mathrm{Sr} / \mathrm{Ca}$ variation and insolation in a day. When we take three-point average of the peak and trough of $\mathrm{Sr} / \mathrm{Ca}$ ratios and the insolation peak for an individual day in Supplementary Fig. S7, there is a positive relation between the insolation peak and the difference of $\mathrm{Sr} / \mathrm{Ca}$ ratios from the peak to trough with a correlation coefficient of 0.848. A similar relationship is observed between the water temperature and the $\mathrm{Sr} / \mathrm{Ca}$ ratio with the coefficient of 0.935 . These data suggests that the $\mathrm{Sr} / \mathrm{Ca}$ ratio may be a proxy the insolation.

The second problematic aspect of our age model is the length of the $\mathrm{Sr} / \mathrm{Ca}$ record represents $\sim 2$ years of calcification, while the entire duration of the giant clam cultivation (27 March 2002 until 14 October 2005) is one-and-half years longer. The starting time of calcification (mid-September 2003) was estimated by counting backwards from the inner edge, which is assumed to have been calcified on the day of collection. This may be due to that the young and juvenile portion of the shell was lost by cutting and grinding processes for making the sample cross section. Another possibility is that the giant clam did not calcify during the first year and half, which seems quite long even after considering the fact that very young and juvenile stages of the giant clam likely did not calcify in any significant manner. Resolving this puzzle is an issue to be addressed in the future, perhaps by marking the times of calcification with enriched isotope tracers.

\section{References}

1. Felis, T. et al. Increased seasonality in Middle East temperatures during the last interglacial period. Nature 429, 164-168 (2004).

2. de Garidel-Thoron, T., Rosenthal, Y., Bassinot, F. \& Beaufort, L. Stable sea surface temperatures in the western Pacific warm pool over the past 1.75 million years. Nature 433, 294-298 (2005).

3. Hart, S. R. \& Blusztajn, J. Clams as recorders of Ocean Ridge volcanism and hydrothermal vent field activity. Science 280, 883-886 (1998).

4. Correge, T. et al. Interdecadal variation in the extent of South Pacific tropical waters during the Younger Dryas event. Nature 428, 927-929 (2004).

5. Abram, N. J. et al. Seasonal characteristics of the Indian Ocean Dipole during the Holocene epoch. Nature 445, 299-302 (2007).

6. Pelejero, C. et al. Preindustrial to modern interdecadal variability in coral reef pH. Science 309, 2204-2207 (2005)

7. Tripati, A. K., Roberts, C. D. \& Eagle, R. A. Coupling of $\mathrm{CO}_{2}$ and ice sheet stability over major climate transitions of the last 20 million years. Science 326, 1394-1397 (2009). 
8. Montagna, P., McCulloch, M., Taviani, M., Mazzoli, C. \& Vendrell, B. Phosphorus in cold-water corals as a proxy for seawater nutrient chemistry. Science 312, 1788-1791 (2006).

9. Ren, H. et al. Foraminiferal isotope evidence of reduced nitrogen fixation in the Ice Age Atlantic Ocean. Science 323, 244-248 (2009).

10. Suzuki, A. et al. Last Interglacial coral record of enhanced insolation seasonality and seawater O-18 enrichment in the Ryukyu Islands, northwest Pacific. Geophys. Res. Lett. 28, 3685-3688 (2001).

11. Omata, T., Suzuki, A., Kawahata, H. \& Okamoto, M. Annual fluctuation in the stable carbon isotope ratio of coral skeletons: the relative intensities of kinetic and metabolic isotope effects. Geochim. Cosmochim. Acta 69, 3007-3016 (2005).

12. Allison, N. et al. Reconstruction of deglacial sea surface temperatures in the tropical Pacific from selective analysis of a fossil coral. Geophys. Res. Lett. 32, L17609 (2005)

13. Allison, N., Finch, A. A., Webster, J. M. \& Clague, D. A. Palaeoenvironmental records from fossil corals: the effects of submarine diagenesis on temperature and climate estimates. Geochim. Cosmochim. Acta 71, 4693-4703 (2007).

14. Bonham, K. Growth rate of Giant Clam Tridacna gigas at Bikini Atoll as revealed by radiography. Science 149, 300-302 (1965).

15. Watanabe, T. \& Oba, T. Daily reconstruction of water temperature from oxygen isotopic ratios of a modern Tridacna shell using a freezing microtome sampling technique. J. Geophys. Res. 104, 667-674 (1999).

16. Aubert, A. et al. The tropical giant clam Hippopus hippopus shell, a new archive of environmental conditions as revealed by sclerochronological and delta O-18 profiles. Coral Reefs 28, 989-998 (2009).

17. Sano, Y. et al. Nano-SIMS analysis of $\mathrm{Mg}, \mathrm{Sr}, \mathrm{Ba}$ and $\mathrm{U}$ in natural calcium carbonate. Anal. Sci. 21, 1091-1097 (2005).

18. Elliot, M. et al. Profiles of trace elements and stable isotopes derived from giant long-lived Tridacna gigas bivalves: potential applications in paleoclimate studies. Palaeogeogr. Palaeoclimatol. Palaeoecol. 280, 132-142 (2009).

19. Klumpp, D. W. \& Griffith, C. L. Contributions of phototrophic and heterotrophic nutrition to the metabolic and growth requirements of 4 species of giant clam (Tridachidae). Mar. Ecol. Prog. Ser. 115, 103-115 (1994).

20. Gillikin, D. P. et al. Strong biological controls on $\mathrm{Sr} / \mathrm{Ca}$ ratios in aragonitic marine bivalve shells. Geochem. Geophys. Geosyst. 6, Q05009 (2005).

21. Carre, M. et al. Calcification rate influence on trace element concentrations in aragonitic bivalve shells: evidences and mechanisms. Geochim. Cosmochim. Acta 70, 4906-4920 (2006)

22. Cohen, A. L. \& Sohn, R. A. Tidal modulation of $\mathrm{Sr} / \mathrm{Ca}$ ratios in a Pacific reef coral. Geophys. Res. Lett. 31, L16310 (2004).

23. Gaetani, G. A. \& Cohen, A. L. Element partitioning during precipitation of aragonite from seawater: a framework for understanding paleoproxies. Geochim. Cosmochim. Acta 70, 4617-4634 (2006).

24. Klein, R. T., Lohmann, K. C. \& Thayer, C. W. Sr/Ca and C-13/C-12 ratios in skeletal calcite of Mytilus trossulus: covariation with metabolic rate, salinity, and carbon isotopic composition of seawater. Geochim. Cosmochim. Acta 60, 4207-4221 (1996).
25. Surge, D. \& Lohmann, K. C. Evaluating Mg/Ca ratios as a temperature proxy in the estuarine oyster, Crassostrea virginica. J. Geophys. Res. 113, G02001 (2008)

26. Meibom, A. et al. Distribution of magnesium in coral skeleton. Geophys. Res. Lett. 31, L23306 (2004).

27. Meibom, A. et al. Compositional variations at ultra-structure length scales in coral skeleton. Geochim. Cosmochim. Acta 72, 1555-1569 (2008).

28. McCulloch, M. et al. Coral record of increased sediment flux to the inner Great Barrier Reef since European settlement. Nature 421, 727-730 (2003).

29. Sinclair, D. J. \& McCulloch, M. T. Corals record low mobile barium concentrations in the Burdekin River during the 1974 flood: evidence for limited Ba supply to rivers? Palaeogeogr. Palaeoclimatol. Palaeoecol. 214, 155-174 (2004).

30. Gaetani, G. A. et al. Rayleigh-based, multi-element coral thermometry: a biomineralization approach to developing climate proxies. Geochim. Cosmochim. Acta 75, 1920-1932 (2011).

31. Shirai, K. et al. Minor and trace element incorporation into branching coral Acropora nobilis skeleton. Geochim. Cosmochim. Acta 72, 5386-5400 (2008).

32. Kunioka, D. et al. Microdistribution of $\mathrm{Mg} / \mathrm{Ca}, \mathrm{Sr} / \mathrm{Ca}$, and $\mathrm{Ba} / \mathrm{Ca}$ ratios in Pulleniatina obliquiloculata test by using a Nano-SIMS; implication for the vital effect mechanism. Geochem. Geophys. Geosyst. 7, Q12P20 (2006).

\section{Acknowledgements}

We wish to thank T. Oba for stimulating discussion, W. Fujiya and D. Kunioka for help in experiments. We also thank Bernd Schone for comments on an early version of the manuscript.

\section{Author contributions}

K.I., K.S. and T.W. performed cultivation of giant clams in the field. S.K. and K.S. prepared the polished sections of the samples and the standard. S.K., K.S. and N.T. developed the method of the NanoSIMS analyses and collected data. Y.S. and N.T. processed and refined the data. Y.S. designed the study and prepared the original manuscript. K.M., K.S. and Y.S. prepared the revised manuscript. All authors discussed the results and commented on the manuscript.

\section{Additional information}

Supplementary Information accompanies this paper at http://www.nature.com/ naturecommunications

Competing financial interests: The authors declare no competing financial interest.

Reprints and permission information is available online at http://npg.nature.com/ Reprintstandpermissions/

How to cite this article: Sano, Y. et al. Past daily light cycle recorded in strontium/ calcium ratios of giant clam shell. Nat. Commun. 3:761 doi: 10.1038/ncomms1763 (2012). 